\title{
Edward Said: Post-colonial Discourse and Its Impact on Literature
}

\author{
Naifa Al Mtairi \\ Dept. of English Language and Translation, Qassim University \\ PO Box 100795, Riyadh 11645, Saudi Arabia \\ Tel: 966-503-939-325. E-mail: hhighflower@gmail.com
}

Received: January 9, 2018

doi:10.5296/elr.v5i1.14287
Accepted: January 27, 2019 Published: January 29, 2019

URL: https://doi.org/10.5296/elr.v5i1.14287

\begin{abstract}
This paper highlights Edward Said's ideology for discerning literary texts that followed the colonial period as a post-colonial discourse. Though some scholars disapprove that notion, Said holds the view that literature is a product of contested social and economic relationships. The West attempts to represent the East and consequently dominates it, not only for knowledge but for political power as well. He assures the worldliness of texts and their interferences with disciplines, cultures and history. Thus, the post-colonial critic should consider the post-colonial literature that might take the form of traditional European literature or the role of the migrant writer in portraying the experience of their countries. The pot-colonial theory with its focus on the misrepresentation of the colonized by the colonizer and the former's attitude of resistance, draws new lines for literature and suggests a way of reading which resists imperialist ideologies.
\end{abstract}

Keywords: Colonialism, Post-colonial, Resistance, Identity, Orient, Occident, Contrapuntal reading, Imperialism

\section{The introduction}

Before going deeply into postcolonialism, it is worth referring firstly to the notions of colonial and colonialism. Colonial can be identified with a process of military and political sovereignty over the colony. It is the act of practicing power and control over foreign territories. Historically, this term refers to a period from the fifteenth to the twentieth centuries when European People established colonies on other continents. This political domination constructs what is called colonialism. Colonialism is an ideology of colonial power that operates to impose control over colonized nation in the field of language in addition to literary and cultural representations. It is a process of regulating what can be said 
with respect to empire. Thereby, it can be classified with reference to colonial discourse. In the meanwhile, imperialism is a concept of colonialism. However, it stretches beyond the latter though both involve power and domination. Culturally, it is a hegemonic operation to subordinate the native culture to the culture of the imperialists.

\subsection{The Influence of Imperialism}

According to Said, the influence of imperialism in the beliefs does not end with the removal of a colonial or imperial power. Thus, imperialism shaped the culture of the colonized, besides, the discourse between the colonized and the dominant empire will continue even with the end of military force of colonialism.

Needless to say, that colonization caused harmful effects. It was a wide disruption for the ways of life, the ways of thinking and most importantly for the culture. The whole situation of dominance and its discursive operations are best translated by Edward Said. Through his Orientalism, The World, the Text, and the Critic, and his Culture and Imperialism, Said draws a picture in which he depicts colonial discourse and its implications.

Considering his analysis of Western discourse, he is severely attacked for ignoring the contribution of Western scholars to understand the Middle East. Nevertheless, Said is held with appreciation worldwide as the innovator of postcolonial discourse. Despite the fact that his influence is considered by some critics to be destructive and fits for political purposes solely, his ideology created positive responses in different aspects and different sciences such as anthropology, geography, social studies and literature. However, the focus here will be laid on literature as a purpose for this study.

\subsubsection{Said's Orientalism}

Since the publication of Orientalism, Said's critique has become the hegemonic discourse which opens a new window and paves the way for a different outlook through which we can approach literature.

\subsubsection{Said's Biography}

The Palestinian American writer, Edward Said was born in Jerusalem in 1935. Though he was the holder of an endowed chair in English and comparative literature at Columbia University, he was an active politician who could display vividly the anguish of his people who suffer colonialism. And he could defend his country in more than one occasion through his speeches as well as his pen. He died 2003 after a long struggle with Leukaemia.

\section{Post-colonial Theory}

With all respect for the former work and some pioneer writers in commonwealth studies who assure the relationship between "the cultural products of the former colonies and the culture of the metropolis." (Bertens, 200), post colonialism in its theoretically form originates in 1978 with the publication of Said's Orientalism. Building on Foucault's discourse, Said changed the agenda of non-western studies (in culture and literature) and directed it to what is called now postcolonial theory. 


\subsection{Discrepancies on Post-colonial}

The latter emphasizes cultural displacements and their effect on identity and how the displaced have defended themselves. Bertens discerns that postcolonial theory takes such displacements, and the hybrid cultural forms to which they lead, as vantage points that allow us to expose the internal doubts and the instances of resistance that the West has suppressed in its steamrolling globalizing course and to deconstruct the seamless facade that the combination of imperialism and capitalism has traditionally striven to present (200).

Therefore, postcolonial theory focuses on the relationship between the metropolis and its colonial subjects, in addition, it focuses on colonial oppression, resistance to colonization, the respective identities of colonizer and colonized and interaction between them, on postcolonial migration to the metropolis, and on cultural exchanges and hybridity of both cultures between the colonizer and the colonized.

With Said's new critique in Orientalism, the focus is paid to Western texts and their representation of the East. Said examines different British and French texts in literature, politics, religion and philosophy to come up with that these texts construct imaginative claims to knowledge about Oriental history and culture.

In his methodology, he makes use of Foucauldian discourse and he himself indicates to it in his own words "unlike Michael Foucault, to whose work I am greatly indebted, I do believe in the determining imprint of individual writers upon the otherwise anonymous collective body of texts constituting a discursive formation like Orientalism." (Orientalism, 23)

Actually, the forms of Western writing that Said has examined are part of Foucauldian discourse as they consist of claims and statements through which knowledge about the Orient is constructed. According to Foucault, Discourse includes all social communicative acts and simultaneously it is influenced by society. Foucault's critique of discourse arises from the hope to develop a more accurate account of human condition in Western society.

In his The Order of Things, he refuses to accept the idea of 'Man' as a centre for the cultural understanding as he is the product of reordering of Knowledge. Power and knowledge are linked through discursive elements. Thus, discourse can affect and be an effect of power, where it can work to produce power, it can undermine it. However, resistance should accompany power as there is no power without it and this encounter discourse can produce new knowledge or new thinking. In other words, power is initiated within the field of struggle and conflict and consequently it generates resistance through discourse.

For Foucault, the discursive formations or functions work to make individuals seem to have certain amount of power, when their productivity is determined by discourse. In addition, he focuses on the rules of governing discourse. Discourse, then is not merely a term for exchanging communication but has a powerful material effect.

\subsubsection{Said's Notion of Post-colonial Discourse}

Depending on discourse theory, Edward Said thinks that the language of Orientalism plays the dominant. It brings opposites together as "natural," it presents human types in scholarly idioms and methodologies, it ascribes reality and reference to objects (other words) of its own making. Mythic language is discourse, that is, it cannot be anything but systematic; one does not really make discourse at will, or statements in it, without first belonging-in some case 
unconsciously, but at any rate involuntarily to the ideology and the institutions that guarantee its existence (177).

Therefore, the power of discourse is related to the social institutions and it is a vehicle for ideology. Moreover, involving in discourse on the side of human will is determined by the social reality which assures the importance of society first and then human will. Then Said confirms that discourse belongs to an ideology or institution and this belonging is "involuntary" as he claims, the idea that displays his acceptance of Discourse theory.

Nevertheless, Said diverges from Foucault as appears from his words "I do believe in the determining imprint of individual writers upon the otherwise anonymous collective body of texts constituting a discursive formation like Orientalism." (Orientalism, 23).

And here we can see that though Said believes that the individual is subject to the forces of society, this same individual has a great role in Discourse.

Back to Western discourse, though it seems to be interested in knowledge, it is associated with a dominant force. And as Foucauldian perspective demonstrates, we work within network of power. However, for Said, western discourse or (Orientalism) about the Orient operates for hegemonic purposes and it aims consciously with a great effort at subordination.

Antonio Gramsci believes that 'hegemony' is domination with approval. He thinks that the ruling class dominates other classes and oppressed them in the time that the rulers convince them that they are working for their benefits and even elevate their culture to the level of the dominating culture and the offspring is domination by consent. In this way Orientalism has legitimized Western imperialism persuading the natives that this new dominating culture represents universal civilization. (Bertens, 204).

However, with Edward Said the matter is totally unconvincing. Western representation of the Orient is not more than a part of Western damaging discourse. He goes further to doubt in sympathy shown by some Orientalists towards Oriental culture or people because they cannot neglect their Eurocentric perspective in addition to their contribution to Western domination. Through Western representation of the Orient, the East is inferior and the West is superior. Thus, sensuality and the primitiveness of the East is versus the rationality and progressiveness of the West. There is always European tendency to rule the world through knowledge of what constituted as 'other'. The West works always as the 'centre' and the East is a marginal 'other'. This interpretation by Said produces a challenging theory and a new perspective of Western writing about the East. Therefore, for Said, Orientalism is a system of representation framed by forces and political activities.

In his Culture and Imperialism, Said studies the relation between culture and empire. That is the relation between imperialism in the West and its range of far territories. He continues focusing on the European texts but with a wide aspect including writings on Africa, India, Australia and the Caribbean. He concludes as he has done in Orientalism with the notion that European think they are not like 'us', thus they deserve to rule and dominate. He continues to seek the seed of resistance through following the discontinuities of colonization. Depending on Foucauldian discourse that operates within fields of power and resistance, Said assures that there is a history of resistance against this universal domination. Through an analysis of narratives like the works of Conrad, Austin, he could understand the limits of imperialism and 
their practices over the colonies ruled by the West. In narratives, he found bare knowledge against which there can be alternative knowledge through resistant readings. However, as narratives can be a site for resistance, it can be used as a legitimization for the culture which makes effort to show difference between 'us' and 'them'. However, it can be a starting point for resistance and a sought after national identity. Thus, as Foucauldian reverse discourse, Said's resistance and counter-knowledge of identity originate from the same dominating Western discourse. Nevertheless, Said calls for what he thinks will be the 'freedom from domination', it is the notion of hybridity as a result of the imperial project which claims universalization. Therefore, in a time Said calls for a national identity, he eventually demonstrates that we have to accept hybridity to have our freedom. Ashcroft says much about this paradox of Said's identity and demonstrates that it is only a piece of a chain of complexities in Said himself. According to Ashcroft, Said is a person located in a tangle of cultural and theoretical contradictions between his westernised persona and political concerns for his Palestinian homeland, between his political voice and professional position. Then he continues "The paradox of Edward Said's identity is the most strategic feature of his own 'Worldliness,' a feature which provides a key to the interests and convictions of his cultural theory. This identity is itself a text which is continually elaborated and rewritten by Said, intersecting with and articulated by all the other texts he writes." $(7,8)$.

Thus, being Palestenian by origin and an American citizen as well, this fact plays an important role in constructing Said's cultural theory. However, he remains faithful to his origin defending his home and focusing much light on the suppression of the colonizer on any colonized territories and its damaging consequences. Nevertheless, he is realistic when calls for 'Worldliness' as it is a compromising solution for this endless imperialism.

While previous studies of the text focus on its functions neglecting the objectives or the forces behind it and the world for such studies is constructed by the text, postcolonial texts represent the world as they are in the real world. Said believes that worldliness is constructed within the text. Thus, writing is a better translation of the forces existed in the world. This notion of worldliness arises the question of how to read the text. For Said, filiation which refers to 'descent' cannot be used in recent complex and progressive civilization, thus affiliation which refers to 'identification through culture' is a suitable critical principle because it provides a new wide look to the text, its existence and the world and the different circumstances around it. Said thinks that post-colonial writers cannot write in isolation from their western European perspective because their works come after western representation of the non-western world. This involves consideration of the postcolonial situation in their texts. It is worth noting here, that Said does not aim to make his theory replaces other perspectives but to be taken in consideration with other forms of criticism. Therefore, literature must be read not as it formally presents but as a product of contested social and economic relationships. This worldliness that Said calls for is 'contrapuntal reading' in Said's terms.

\section{The impact of Post-Colonial Theory on Literature}

Said's critique faces some disapproval on the side of some scholars. They think that his conception of Western discourse and the way it represents the 'Orient' as marginal and the 'Occident' as central means that the East is stable unchangeable and cannot express itself. Thus, the West goes on his way to represent the East and consequently dominates it where he 
deserves, in this way Said denies knowledge for its own sake as he associates it with political power and he doubts any scholarship can come close to that truth. Moreover, Said is attacked for his neglecting the positive aspects of Orientalism. That claim was based on the view that everyone studies the 'other' distorts it, therefore in this respect Islamic Culture also has a distorted perspective of the 'other.' Actually, these accusations base their grounds on some aspects of Said's theory trying to deconstruct it according to their purposes forgetting that Said is speaking about the Western colonization and imperialism for the East and the truth of their domination to Eastern countries for damaging purposes.

Whatever condemnation against him, and whatever attempts to constrict his ideology to politics, Said is the originator of postcolonial theory and is a source of inspiration for many scholars in different fields of knowledge not only in the East but worldwide. Many scholars and critics respond positively to Said's critique and either began to work on it, expand it or study some issues they think Said did not say much about. Therefore, he seems to create a new vision, provide a new telescope with which we can apprehend the new world as it is.

Homi Bhabha is one of those who are influenced by Said's thought. He takes another side of investigation to study the cultural interaction between colonizers and colonized which Said does not address. This interaction had been denied in earlier writings on colonialism as there were some writers who held the position that there is no contact between the two, but relations of power and submission. The West remains the master and the colonized is an instrument of production. However, there were some people who take Western culture as civilized and follow Western values but never been contented with the idea that their sons and daughters be affected by this culture. Bhabha believes that the encounter between the two extremes (he refers to the colonizer as the British and the colonized as the Indian) affects both. He speaks about the identity of the colonizer and demonstrates that it is constructed by the interaction with the colonized. The colonizer's identity is not self-sufficient and has no origin in itself though it has been shaped before by Western discourse. This idea is very clear in the colonizer's dependency on 'other.' For Bhabha, the colonizer's discourse which is the most effective weapon is less stable and secure than he thinks because colonial power is under the threat of resistance. This resistance is a sign of the colonized recognition of his priority. Though Said keeps the 'Occident' and the 'Orient' firmly apart and investigates Western representations of the East, Bhabha with his focus on the encounter between them he contributes to Postcolonial theory by producing his notion of hybridity which refers to the melting of cultural forms but with powerful presence of the powerful authority. Ashcroft and Griffiths assure that "post-colonial cultures are inevitably hybridised, involving a dialectical relationship between European ontology and epistemology and the impulse to create or recreate independent local identity."(95).

This means that the resulting identity is a new one. Therefore, Bhabha's emphasis on interaction and hybridity extend our recognition of what happens in the colonial situation.

Another prominent postcolonial theorist builds on Said's critique is Gayatri Chakravorty Spivak. She is an academic working in the West, and she admits that her position there separates her from her country of origin, India. She is distinguished by her feminist agenda which includes the complicity of female writers with imperialism. Like Said, Spivak grounded her study on fiction because she saw that there is no nineteenth-century British 
fiction without indication to imperialism directly or indirectly. Through her reading of Charlotte Brontes Jane Eyre, she states that literature plays an important role in cultural representation and that feminist perspectives form a part of that role. Though Said and Bhabha neglect the question of difference, as Said is accused of gender blindness because feminist scholars claim that female representations are different from male ones, Spivak focuses on the voice of difference. She continues in her analysis of difference to social class.

In her strategy, she studies the subaltern which describes the lower layers of colonial and postcolonial society such as the unemployed and the day labourers. What of interest here for Spivak is the female subaltern because she thinks that if the subaltern has no place to speak, the subaltern as female is more deeply in 'shadow.' Her target here is not to speak for, but to save the female subaltern from misrepresentation. Therefore, Spivak with her strategy display some issues that are ignored by Said but still his influence is very clear on feminism as she identifies herself a feminist, which confirms Said's impact even on literature and criticism.

As an echo of Said's critique, the condition of knowledge, empire and post colonialism

invade many books which depend on an analysis of literary works. Scholars began to examine the narrative fictions of nineteenth- century writers in terms of their constitution of an empire united by information instead of force. This new tendency is raised by the fact that fiction works on a symbolic ground rather than dealing with real identity. Thus, the study of fiction becomes "a textual evidencing of the means through which the thinking of the fictive control of empire was wrought." (McGowan, 147).

Therefore, such studies imply a removal from the paradigms of power and knowledge which are available in works by Michael Foucault and Edward Said. According to some scholars who practise this analysis, knowledge is grasped as something substitutes for power as an extension of empire in colonial world. However, this concept can be interpreted through reference to the difficulty of empire in nineteenth century due to what Said calls resistance. The reversal of power has weakened the strength of the colonizer which leads to adopt direction of knowledge. Nevertheless, it is worth mentioning that the text here does not concern with the structure or the form of knowledge but rather with knowledge produced in relation to the centre-other language that Said indicates.

Following the work of Edward Said's Orientalism, many writers focus on the association between the subjects of literature and the formation of colonial subjects. This study shows complicity between the literary text and the process of Western political domination.

As a result, the nineteenth century literary texts begin to be read in the light of Bhabha's term of the encounter between the colonizer and the colonized. The readings of these texts focus on how the two identities of the 'centre' and the 'other' are constructed within that colonial condition.

Moreover, the literary text of the nineteenth century woman writer becomes a key issue as some critics unite the postcolonial with the concern of the discourse of feminism. The female writer functions in the scope of the imperialist project. Through reference to the feminist history of the novel, clearly it has colluded with the strategy of imperialism. The works of Charlotte Bronte and Aphra Behn for example, are important for their interest in issues of sexuality, authenticity and the politics of language. It seems that feminist criticism masked 
the imperialist indications in their writings within a discourse of feminist empowerment of all women. Therefore, Said's theory though it does not involve the question of gender inspires critics to examine the works of woman writer. Consequently, these works gain a prominent position more than before and prove to have a role in the process of colonization intentionally or unintentionally.

Elleke Boehmer, South African novelist and literary critic, argues that the migrant writers produce the definitive form of post-colonial writing as it is studied in Western universities. Those 'transnational' writers practise the literary strategies that make them appealing to current Literature departments. The migrant writing with its double culture, inclusion of different writing styles, techniques to document evidence and historical events mingled with fictional characters, is attractive to post-colonial studies. In the light of post colonialism, the migrant writers gain much importance aided with their living in First World countries which give them chance to be interviewed by post-colonial critics as well as the availability of publishing their books easily. This attraction leads migrant writers to adopt all Western techniques while they are different. However, other migrant writers connote resistance of dominant discourse, resistance of a literary canon, rewrite a certain version of history or challenge the common view of politics. (Green and Lebihan, 293)

Post-colonial literature is classified by some critics as written texts produced by authors born in colonized countries but in most cases their countries gain independence. Therefore, this kind of literature tends to portray the struggle of subject people to face poverty, financial instability and cultural disturbance. The educational systems and the social constitution of their countries seem to be inferior to the old European dominated system though most of these countries are independent of former colonization. "[ I]t has been the project of postcolonial writing to interrogate European discourses and discursive

strategies from a privileged position within two worlds." (Ashcroft, Griffiths and Tiffin, 95).

Thus, the question of minority and being a native person in a country recently ruled by non native is another major theme. Postcolonial literature depicts uncertainty of national and cultural identities of those who are trying to construct a nation under colonial rule. Usually this kind of literature tends to use some traits to tell a story like satirical novel, magical or realist novel. It is the light of Edward Said's critique which evokes these questions or themes in post-colonial literature which imply the spirit of resistance.

Edward Said was first and foremost a literary critic and his ideology originates from examining literary texts. Therefore, he left clear marks on the field of criticism especially with his book The World, the Text, and the Critic which won Rene Wellek prize of the American Comparative Literature Association in 1983. Said insists on the worldliness of texts and assures the interference of disciplines, cultures and histories in the text. Some literary critics are discomforted of this strategy and think that it leaves unpleasant and disturbing effects on the aesthetic text. However, as a sequence of the misrepresentation and the systematic distortions of the East in the Western texts he examined, Said confirms that the study of literature is a historical task and not only an aesthetic one. Thus, the literary criticism began to receive the work as a part of the social world, human life and the historical time in which it is written and interpreted. The post-colonial critic should take in consideration some issues to seek. He/she should discern the post-colonial writer of European descent as opposed 
to those of native descent, the fact that some postcolonial literature takes the form of traditional European literature, the difference in experience and opportunity between women and men in post-colonial nation and the role of the migrant writers in portraying the experience of their countries. These investigations are initiated as an echo of Said's theory of criticism which tries to keep the literary text in association to social, historical and political conditions surrounding it.

Though Said's critique is overshadowed in the field of literature by some of his opponents due to its interventions in politics and history, his postcolonial theory with its focus on misrepresentation of the colonized by the colonizer and its attitude of resistance, draws new lines for literature and suggests a way of reading that resists imperialist ideologies. He believes that postcolonial literary contexts include colonial situation in the real world, thus, he originates a new perspective compatible with that new situation. His call is faced by many positive responses which left distinctive impact on literature and literary criticism.

\section{Acknowledgement}

The research is granted for the memory of my dear father, the memory of my dear brother and my supportive mother.

\section{References}

Ashcroft, B., \& Pal, A. (2001). The Paradox of Identity. London: Routledge. https://doi.org/10.1080/13504630120087190

Ashcroft, B., Gareth, G., \& Helen, T. (1995). Postcolonial Literature and Counter Discourse. London: Routledge.

Bertens, H. (2001). Literary Theory. London: Routledge.

Cook, R. (2010). Edward Said's Orientalism: Influence and limitations. Culture and Literature 2. 1 (2008). Retrieved from http://humanitiescenter.nsysu.edu.tw/doc

Curran, J., \& Susan, R. T. (2010). Said's Culture and Imperialism. Review Essay. Retrieved from http://www.csudh.edu/dearhabermas/said01.htm

Foucault, M. (1970). The Order of Things: An archaeology of the human sciences. London: Routledge.

Green, K., \& Jill, L. (1996). Critical Theory and Practice. London: Routledge.

McGowan, K. (1993). The Year's Work in Critical and Cultural Theory. Oxford: Blackwell Publishers. https://doi.org/10.1093/ywcct/3.1.1-s

O'Connor, E. (2003). Preface for a Post-Poscolonial Criticism. Victorian Studies, 45(2), 217-246. https://doi.org/10.2979/VIC.2003.45.2.217

Said, W. E. (1983). The World, the Text and the Critic. NewYork: Pantheon.

Saunders, R. (2005). Risky Business: Edward Said as Literary Critic. Comparative Studies of South Asia, Africa and the Middle East, 25(3), 522-32. https://oi.org/10.1215/1089201X $-25-3-522$

Yew, L. (2002). Political Discourse: Theories of colonialism and Postcolonialism. On Categorizing Postcolonial Theorists. 


\section{Macrothink

\section{Copyright Disclaimer}

Copyright reserved by the author(s).

This article is an open-access article distributed under the terms and conditions of the Creative Commons Attribution license (http://creativecommons.org/licenses/by/3.0/). 